\title{
Impact of physical self-perception in surgical result of patients with adolescent idiopathic scoliosis
}

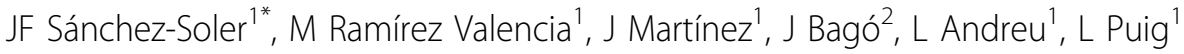 \\ From 8th International Conference on Conservative Management of Spinal Deformities and SOSORT 2011 \\ Annual Meeting \\ Barcelona, Spain. 19-21 May 2011
}

\section{Background}

A possible alteration of the self-image in patients with adolescent idiopathic scoliosis may influence the surgical result.

\section{Objective}

Assess the correlation between the decrease in BMI and physical alteration of perception as measured by the Body Shape Questionnarie (BSQ-14) [1] in AIS with the end result perceived by patients after surgery.

\section{Materials and methods}

Prospective study 32 patients surgery AIS from 2003 to 2006. 3 males-29 females. Mean age 15.9 years. BMI and Cobb angle was measured before surgery. After we measure Cobb, the physical alteration of perception by BSQ14 , the postoperative satisfaction with a questionnaire of 8 questions and the SRS-22 [2].Patients were grouped according to BMI, BMI $<18$ (group 1) and $>18$ (group 2) and to BSQ-14 >40 (group 1a) and BSQ $<40$ (group 2a).

\section{Results}

The mean BMI was $19.6 \mathrm{~kg} / \mathrm{m}, 37.5 \%$ a BMI $<18$. Mean preoperative Cobb $64.51^{\circ}$ and the average correction rate of $56.57 \%$.

Patients in group 1 showed worse results in the questions refered to the satisfaction of physical appearance after surgery. Group 1 also had poorer results of SRS-22 in self-image, subtotal dimension and the strong tendency in the dimension of satisfaction.

Patients in group 1a showed worse results the questions of satisfaction concerning self-image and overall satisfaction. In the SRS-22 in the dimension pain, selfimage,satisfaction dimension, subtotal and total SRS.

${ }^{1}$ Parc de Salut Mar - Barcelona, Spain

Full list of author information is available at the end of the article
We found no correlation between the degree curve correction with any questionnaire.

\section{Conclusions}

Patients with a BMI $<18$ and patients with alteration of physical perception (BSQ>40) have a worse surgical result.

\section{Author details \\ ${ }^{1}$ Parc de Salut Mar - Barcelona, Spain. ${ }^{2}$ Hospital Vall D'Hebron - Barcelona, Spain.}

Published: 27 January 2012

\section{References}

1. Lavoisy G, Guelfi JD, Vera L, Dardennes R, Rouillon F: Evaluation of perturbed body image in eating disorders using the Body Shape Questionnaire. Encephale 2008, 34(6):570-576.

2. Climent JM, Bagó J, Sánchez J, et al: Validity of the Spanish version of the Scoliosis Research Society -22 (SRS-22) Patient Questionnaire. Spine 2005, 30:705-709.

doi:10.1186/1748-7161-7-S1-O10

Cite this article as: Sánchez-Soler et al:: Impact of physical self-perception in surgical result of patients with adolescent idiopathic scoliosis. Scoliosis 2012 7(Suppl 1):010.

Submit your next manuscript to BioMed Central and take full advantage of:

- Convenient online submission

- Thorough peer review

- No space constraints or color figure charges

- Immediate publication on acceptance

- Inclusion in PubMed, CAS, Scopus and Google Scholar

- Research which is freely available for redistribution

Submit your manuscript at www.biomedcentral.com/submit C BioMed Central 